\title{
PROTESTANT PROPAGANDA IN A COLD WAR OF RELIGION: FROM THE HARTLIB CIRCLE TO THE SOCIETY FOR PROMOTING CHRISTIAN KNOWLEDGE
}

\author{
Sugiko Nishikawa
}

\begin{abstract}
This article considers how, impelled by confessional divisions caused by the Reformation, a general sense of pan-Protestant community grew across Europe, and its members launched a long battle against Roman Catholicism far beyond the 16th century. Indeed, it continued into the mid-18th century, the so-called Age of Reason. If it cannot necessarily be described as an open war of religion like the Thirty Years War, it was at least a cold war. From their points of view, the Protestant minorities threatened by the Roman Catholic Counter Reformation, such as the Waldensians in northern Italy and the Lithuanian Calvinists, stood on the front line in this war. Thus, financial support was regularly offered by the Protestant churches in Great Britain and Ireland to their distressed brethren across the continent, university scholarships were set up for students from Catholicdominated areas, and plans were drafted for a Protestant union in Europe, from a military level to an ecclesiastical one. It is in this context that we must understand how apparently strange a phenomenon as British support for the translation of the Bible into Lithuanian developed. The author sees Chylinski's activities in the tradition of learning and charity exhibited in the 1650s by the three leading members of the Hartlib philosophical circle, namely, Samuel Hartlib (originally from Elbing), Jan Amos Comenius (from Moravia), and John Dury (born in Edinburgh, he spent his early life in various places in northern Europe), who were, in a sense, Protestant refugees to England from north-central Europe. After Chylinski, British support for Lithuanian Protestants did not end. She traces the work of Robert Boyle and the foundation of the Society for Promoting Christian Knowledge (1699), which organised relief for Žemaitijan Calvinists in the early 1730s.
\end{abstract}

Impelled by confessional divisions caused by the Reformation, a general sense of the Protestant community grew across Europe, and its members launched a long battle against Roman Catholicism far beyond the 16 th century. Indeed, it continued into the mid-18th century, 
the so-called Age of Reason. If it cannot necessarily be described as an open war of religion like the Thirty Years War, it was at least a cold war. From their points of view, the Protestant minorities threatened by the Roman Catholic Counter Reformation, such as the Waldensians in northern Italy and the Lithuanian Calvinists, stood on the front line in this war. Thus, financial support was regularly offered to the distressed brethren across the continent, university scholarships were set up for students from Catholic-dominated areas, and plans for a Protestant union in Europe, from a military level to an ecclesiastical one, existed throughout the period. ${ }^{1}$

These initiatives were often closely associated with religious education as propaganda and with confessional networks: the two enterprises generally worked in tandem. Throughout the 16th century Roman Catholics were far more advanced, as is shown by the many examples of Jesuit activities around the world. Perhaps we can regard the Hartlib circle as one of the first Protestant ventures of this sort attempting to counter Roman Catholicism. As is already well known, the circle was an intellectual network of contacts and correspondence, formed during the time of the Thirty Years War and the British War of the Three Kingdoms, the last wars of religion in Western and Central Europe, and which pursued an ideal society (mainly based on a Protestant union) through correspondence and educational activities. Its members included Andrew Marvell, John Milton, Theodore Haak and René Descartes. However, the three leading members of the Hartlib circle, namely, Samuel Hartlib (originally from Elbing), Jan Amos Comenius (from Moravia), and John Dury (born in Edinburgh,

${ }^{1} \mathrm{~S}$. Nishikawa, 'The SPCK in defence of Protestant minorities in early 18 th-century Europe', Journal of Ecclesiastical History, 56 (2005), pp 730-48. As to English financial support for the Lithuanian Protestants, see S. Nishikawa, 'Across the Continent: The Protestant Network between the Society for Promoting Christian Knowledge (SPCK) and Kedainiai', in Kultūru Sankirtos, ed. Z. Kiaupa, J. Kiaupienè, E. Rimša, J. Sarcevicienè (Vilnius, 2000), pp. 296-308. For the Waldensians, see 西 川杉子『ヴァルド派の谷へ 一近代ヨーロッパを生きぬいた異端者たち』

(S. Nishikawa, To the Waldensian Valleys: the survival of descendants of the medieval heretics in Modern Europe (Tokyo, 2003). It was a common practice among Protestant universities, such as Marburg, Königsberg, Edinburgh, Aberdeen, Geneva and Leiden, to offer scholarships for students from predominantly Roman Catholic areas. As to students from Lithuania, Poland, Transylvania, and the Waldensian valleys in Piedmont, see respectively, LMAB RS, F40-362; W. Tomaszewski, The University of Edinburgh and Poland: An Historical Review (Edinburgh, 1968); Keseru" Ba'lint, ed. Peregrinuslevelek, 1711-1750 (Szeged, 1980); Nishikawa, 'To the Waldensian Valleys', pp. 78-85, 105-10. 
he spent his early life in various places in northern Europe), were, in a sense, Protestant refugees to England from north-central Europe. All maintained their own continental connections and contributed greatly to the development of the European-wide Protestant interest of the late 17 th century which formed a confessional and ecclesiastical network. ${ }^{2}$

The ideas and networks of the Hartlib circle were taken up by benefactors of Chylinski's Bible project in the late 1650s. As the studies by Gina Kavaliūnaite show, it was John Dury who recommended the Lithuanian Bible project to Robert Boyle, a prominent natural philosopher based in Oxford and the son of an influential Anglo-Irish aristocrat, and to other Oxford professors, succeeding generations of the Hartlib circle, who were greatly preoccupied by the anti-Roman Catholic project of translating scripture into native languages. ${ }^{3}$ The activities of Boyle and his associate should be located in the Protestants' long battle of religion. Although the peak of religious war was apparently over in many parts of Western Europe in the course of the $1650 \mathrm{~s}$, Boyle and his associates together felt they were living in an era riven by murderous ideological divisions between them and Roman Catholics. The ignorance of all benighted peoples and loosening Christian morals were in particular believed to be exploited by the Roman Catholics to extend their influence. Accordingly, the group around Boyle focused its efforts on combating these problems among the poor, and making them part of a pious Protestant community. The distribution of religious tracts (very much anti-popish ones) and Bibles was vital as his Protestant propaganda tool. Not only did Boyle support the Lithuanian Bible project and publish anti-popery tracts, but he also financed Welsh, Gaelic, Turkish, Algonquin and Malayan Bible projects. ${ }^{4} \mathrm{He}$ became an active supporter of propagating the Church of England in New England.

${ }^{2}$ G.H. Turnbull, Hartlib, Dury and Comenius: Gleanings from Hartlib's Papers (London, 1947); G.H. Turnbull, 'Samuel Hartlib's Influence on the Early History of the Royal Society', Notes and Records of the Royal Society of London, 10 (1953), pp. 101-30; M. Greengrass, M. Leslie, T. Raylor eds. Samuel Hartlib and Universal Reformation: Studies in Intellectual Communication (Cambridge, 2004).

${ }^{3}$ G. Kavaliūnaite, 'Introduction', Samuelio Boguslavo Chylinskio Biblija: Senasis Testamentas, ed. Kavaliūnaitè (Vilnius, 2008). As to Boyle's support, see also The Correspondence of Robert Boyle, (edd.) M. Hunter, A. Clericuzio, L.M. Principe, 6 vols (London, 2001), I, pp. 412-13, II, pp. 7-10, 409, VI, pp. 239-44, 298-399. As to Oxford professors who supported Chylinski, see I. Lukšaite, 'Samuelio Boguslavo Chilinskio Biblijos vertimo ị lietuvių kalbą pagrindimas', Knygotyra, 36 (2000), pp. 248-74.

${ }^{4}$ T.C. Barnard, 'Protestants and the Irish Language, c. 1675-1725', Journal of Ecclesiastical History, 44 (1993), pp. 243-72. 
Boyle had close personal links with the Hartlib circle. He became a relative of John Durys through marriage, and Dury's daughter was married to Henry Oldenburg, Boyle's life-long protégé and another immigrant from Central Europe (from Bremen to London), who worked at one time for Boyle's sister Lady Ranelagh, and became first secretary of the Royal Society, founded in 1660. It is evident that the Royal Society was one of the institutions which took over the intellectual interests as well as the continental networks of the Hartlib circle.

In the 1680 s, the threat posed by Louis XIV of France gave new impetus to religious antagonism. His expansionist policies, and attempts to eliminate Protestants within his sphere of influence, enhanced the sense of crisis of Protestantism in Europe. Worrying news came not only from France: the Roman Catholic succession in the Rhine Palatinate and the massacre of the Waldensians in Piedmont took place within a short space of time around James II's succession. The success of the Counter Reformation in Poland-Lithuania, Silesia and Transylvania also loomed large. However, the Protestant confessional network developed further in this time of crisis. Many historians recognise that the Huguenot diaspora in the 1680s and the Waldensian exile in the 1680s and 1690s were sustained, supported and expanded by a transnational confessional network, which often overlapped with diplomatic, academic, mercantile, military and family networks. A notable example is that of the Huguenot galley slaves in the French navy. ${ }^{5}$ Shocked by the harsh situation in which the captured Huguenots were held (only a third of them survived the first year in captivity), many co-religionist groups abroad organised regular propaganda campaigns to spread word of their plight across Europe. They also raised money, which was eventually delivered to Huguenot galley slaves through financial and commercial networks, and kept them alive. Generally, Protestant setbacks in the 1680 s were a stimulus to action: Protestant churches in various territories responded by developing transnational networks and deeper solidarity. In England, Boyle and his associates' ideas were carried forward by the next generation, the founding members of the Society for Promoting Christian Knowledge, the SPCK, founded in $1699,{ }^{6}$ which some

\footnotetext{
${ }^{5}$ As to Huguenot galley slaves in the reign of Louis XIV, J. Marteilhe, Mémoires d'un galérien du Roi-Soleil, ed. A. Zysberg (Paris, 1989).

${ }^{6}$ The Society was founded on 19 March 1699 (New Style) (the Gregorian calendar which was 11 days ahead of the Julian calendar in the early 18 th century), yet in
} 
of them recognised as a Protestant version of the Sacra Congregatio de Propaganda Fide. ${ }^{7}$

From its very inception, the SPCK called on Protestants to unite against the 'progress of popery ... all over Europe' and began forming correspondence networks with continental Protestants. Through its networks, the SPCK gathered information about the continental Protestants, organised relief activities for them, and distributed antiCatholic tracts. Although the evidence is circumstantial, it is highly likely that the SPCK took ideas and personal connections from previous generations who worked to unite European Protestants, such as John Dury, Robert Boyle and Henry Compton. ${ }^{8}$ Leading members, such as John Chamberlayne, Sir John Philipps, Dr Frederick Slare and Henry Hoare, also had strong European connections of their own, and many were involved in the activities of the Royal Society. In fact, Slare, the son of a Palatine refugee, was a laboratory assistant to Robert Boyle in his last years. As to their European connection, take Henry Hoare, for example: his family bank, which was deeply involved in the financial aspects of the SPCK, had its own network of agents on the Continent. Thomas Hoare, Henry's brother, after his education with merchants in Amsterdam, worked in Hamburg, and Henry apparently used him to keep up his contacts with August Hermann Francke, a Pietist leader in Halle. ${ }^{9}$ When Henry was burdened with the education of a young boy of the family, he left him in Francke's care through Thomas. It is fairly certain that the SPCK made the most of Hoare's network, and vice versa. ${ }^{10}$ Sporadic as this may have been,

this period in England the year was taken as starting on 25 March, consequently according to Old Style (the Julian calendar) the Society was founded on 8 March 1698. Some historians, as well as the SPCK's official site, still regard the year 1698 as the year of the SPCK's foundation.

${ }^{7}$ S. Nishikawa, 'English Attitudes toward Continental Protestants with Particular Reference to Church Briefs c. 1680-1740' (unpublished PhD dissertation, University of London, 1998); Nishikawa, 'The SPCK in defence of Protestant minorities'.

${ }^{8}$ The Society kept papers about the projects drafted in the name of John Dury. The SPCK archives, London, Wanley MS, CS3, fos. 137-140. The SPCK archives have now been transferred to Cambridge University Library.

${ }^{9}$ In May 1699, only two months after its foundation, Francke was chosen as the first foreign corresponding member of the Society. Society Minute, 11 May 1699, printed in A Chapter in English Church History: Being the Minutes of the Society for Promoting Christian Knowledge for the Years 1698-1704, ed. E. McClure (London 1888), p. 24.

10 J. Black, The English and the Grand Tour (London 1985), pp. 135-41; 西 川杉子「よい子のヘンリと兄弟たち--18世紀ロンドン銀行家一族の子弟教 育」(S. Nishikawa, “Good Henry” and his Brothers: Educating the Children of 
the SPCK made great efforts to become involved with Protestants on the Continent. The SPCK's correspondence network, beginning with the Halle Pietists and Swiss divines, soon expanded from Russia to the Italian free port of Livorno.

The SPCK also sent some agents to the Continent. A most reliable conduit between the SPCK and continental Protestants was Robert Hales, younger brother of a Kentish baronet, who was eager to further the Protestant cause in Europe, and promoted the SPCK publication projects around middle and northern Europe throughout the reign of Queen Anne. As early as March 1704, Hales sent the translation of an account concerning 'the deplorable estate of the Protestant religion in Lithuania and Samogitia'. In the same year, Hales came to the court of Copenhagen. While distributing tracts of the SPCK, such as the Soldier's Monitor, and propagating the Society's intentions, he met not only Prussian courtiers but also representatives and nobles from Russia, Saxe-Gotha, Lüneburg and Lithuania. In August he reported on the reception of the Soldier's Monitor in northern Europe:

[Hales] certifies his presenting the Soldier's Monitor to the Queen of Poland and the Duke of Saxe-Gotha who received it very favourably ... at Cassel there are $4000 \mathrm{Sol}$ dier's Monitors and as many of the papers against swearing, already printed in order to [be] dispersed amongst the Landgrave's soldiers ... a Livonian divine has promised to turn some of our little tracts into Livonian, and Saxon divines [turn] some other [tracts] into Wendish [the Lusatian language] ... [Hales] hopes Dr Brink will turn the Soldier's Monitor into Danish. ${ }^{11}$

Backed by members, including the Archbishop of Canterbury, he also had some anti-popery tracts translated into the 'Bohemian tongue' and possibly into Russian as well. ${ }^{12}$ Hales was also welcomed in Berlin, where Daniel Ernst Jablonski, a grandson of Comenius and an active member of the SPCK, worked industriously in the Protestant interest. ${ }^{13}$ In 1705, an observer wrote that the books distributed

an Eighteenth-century Banking Family', Kobe University Yearbook of History, 17 (2002), pp. 33-37). For example, the Hoare family had a long business partnership with Mordecai Hamburger, alias Marcus Moses, an Ashkenazi, whose family network expanded across Europe. See Hoare's Bank Archives, Copy Letter Book 1701-6, fo. 436; Book of Accounts 1707-1712; file box 24/14.

${ }^{11}$ SPCK, Minute Book, vol. 1, fo. 302.

12 Ibid., vol. 2-4, fo. 61.

${ }^{13}$ S. Nishikawa, 'Die Fronten im Brick: Daniel Ernst Jablonski und die englische Uniterstützung kontinentaler Protestanten', in Daniel Ernst Jablonski: Religion, Wissenschaft und Politik um 1700, ed. J. Bahlcke and W. Korthaase (Wiesbaden, 2008), pp. 151-68. 
by Hales were exceedingly well received at the court of Berlin. The courtiers and kings of Prussia and Sweden vied with each other in praising the SPCK tracts:

[The Prince of Prussia] pulled out of his pocket one of the Soldier's Monitors [distributed by Hales] in this great council, and told them that he had read it over with great satisfaction. The Baron Fuserus did also express his being affected by it, and the King ordered that every one of his soldiers should have one given him, and his Majesty is pleased to take one with him in all his expeditions. The King of Sweden has done the same, with the addition of the Caution of Swears at the end of it. ${ }^{14}$

Hales was even asked to recommend 'some good books' to the tsar's son. ${ }^{15}$ Encouraged by this reaction, the leading members in London responded swiftly to reports and requests from Berlin, and arranged facilities for Hales. ${ }^{16}$ In 1706, Hales was informed in Dresden that 'the Roman Catholics seduce many Muscovites to popery, upon pretence, that the difference between the Greek \& Latin churches is not essential.' Thus, in order to save Muscovites from the hands of popery, he immediately requested the Society to send 'a small treatise demonstrating the errors of the Roman Church, with regard to the Greeks'. ${ }^{17}$ By 1712, the High Dutch versions of the Society's annual report were dispersed 'not only through a great part of Germany but have been sent as far as Moscow ... where some had read the Account of Charity Schools in England. Accordingly, a Pietist in Moscow received some donations and half of which was to be paid to the hospital in Halle, and the other half to the Society for Propagating [sic] Christian Knowledge at London.' ${ }^{, 18}$

Hales and the other continental members also gathered information on Protestantism where it was in the front line against the Roman Catholic powers. In the course of Queen Anne's reign, the English government began to rely on the SPCK network to organise relief activities for the continental Protestants. With its help, Queen Anne organised nationwide fundraising campaigns for the Orangeois (the Protestants of the Principality of Orange), ${ }^{19}$ the Armenians, the Ober-

${ }^{14}$ SPCK, Minute Book, vols. 2-4, fo. 323.

${ }^{15}$ Ibid., vol. 1, fos. 288, 289.

${ }^{16}$ Ibid., fos. 287, 288, 289, 290.

${ }^{17}$ Ibid., fo. 399.

18 SPCK, Abstract Letter, Received, no. 3061.

19 S. Nishikawa, 'Protection des intérêts protestants: les activités de soutien des anglais en faveur des orangeois', La principauté d'Orange du Moyen Âge au XVIIIe siècle. Actualité de la recherche historique: Mémoires de l'Académie de Vaucluse, 9(4) (2008), pp. 151-68. 
barmen church, and the Palatines. King George I did similarly for the Protestants in Poland and Transylvania. Queen Anne also used the SPCK to gain the release of French galley slaves.

In the course of the reign of Queen Anne, distressed continental Protestants turned their eyes on the SPCK and sought its advice. In early 1714, John Holling of Hanover wrote:

... that the provost of Wolgast by name von Platen a Dr in divinity having collected some opinions there and [in] other parts of Germany towards rebuilding the church in said town, which together with the whole town was reduced to ashes by the Muscovites, had desired him to enquire of his friends in England whether it might be advisable for him to go thither to solicit charities for this purpose, and particularly whether the Society would be pleased to countenance him therein; he sends with his letter a printed narrative in High Dutch representing the miserable condition of those poor people, the contents of which he desires may be communicated to the Society by Mr Chamberlayne [a leading member of the SPCK]. ${ }^{20}$

This letter shows that the Protestants in the Baltic region were well aware of the role of the SPCK in English charitable activity.

In the 1720s, English monarchs were still being asked to order nation-wide fund-raising campaigns by continental Protestants, but it was rarely done. It seems reasonable to suppose that England had in the course of the early 18th century lost the sense that it was a pillar of the Reformed religion in Europe and had departed from Protestant internationalism. The SPCK retained its sense of European perspective a little longer. When the Protestants in Kedainiai and Salzburg asked for help from England in the early 1730s, a royal order was not issued, but instead the SPCK undertook a private campaign to raise subscriptions. Yet, by the middle of the 18th century, the SPCK withdrew not only from relief activities but also from cooperation with foreign Protestants. The first generation of the SPCK could identify their own possible fate with that of their continental brethren. The perception of the next generation was different and, to some extent, more anglocentric. The religious cold war was over by then. As the imminent Catholic threat faded away from the English point of view, the SPCK lost interest in the front lines over the Continent and its watch over them.

${ }^{20}$ SPCK, Abstract Letter, Received, no. 3853. 
Author Details

Professor Nishikawa is a graduate of Rikkyo University (Tokyo), who gained her $\mathrm{PhD}$ at University College, University of London, in 1998. She is currently associate professor of history in the British Section of the Graduate School of Arts and Sciences at the University of Tokyo. She specialises in Protestant communications networks in early modern Europe from the British Isles to the Baltic and Mediterranean seas.

Contact address: vzq12556@nifty.ne.jp

\title{
PROTESTANTŲ PROPAGANDA ŠALTAJAME TIKĖJIMŲ KARE NUO HARTLIBO ŠALININKŲ IKI DRAUGIJOS KRIKŠČIONIŲ ŽINIOMS PASKATINTI (SPCK) VEIKLOS
}

\author{
Santrauka
}

\section{SUGIKO NISHIKAWA}

Autorè nagrinejja protestantų ir katalikų bendruomenių priešiškumą XVII a. Europoje, kylant suvokimui, kad visi protestantai priklauso vieningai bendruomenei, kurios nariai turi pareigą materialiai remti savo tikejjimo brolius prieš bendrą priešą - katalikybę (tuo būdu mažinant katalikų valstybių grèsmę Didžiajai Britanijai ir Olandijai). Nors negalima kalbèti apie atvirą XVII a. vidurio religijų karą, tačiau tuometinejje tarptautinejje politikoje galima ižvelgti šaltojo tikejjimų karo bruožų. Tokiam britų mąstymui pirmojoje karo linijoje stovejjo ịvairios protestantu bendruomenès nuo Šiaurès Italijos valdiečių iki Lietuvos evangelikų reformatų. Nuo XVII a. vidurio Didžiosios Britanijos bei Airijos parapijose buvo renkamos pašalpos užjūrio protestantams remti, steigiamos stipendijos užsienio studentams, planuota kurti karinę sajungą prieš katalikų valstybes. Tokiame kontekste Chylinskis gavo materialinès bei dvasinės paramos Biblijai versti į lietuvių kalbą. Autoré parodo tarptautinius tikejjimo bei mokslo ryšius tarp vietinių britų mokslininkų, Anglijoje prieglobstį suradusių Europos protestantų veikejjų (iš Elbingo kilusio Samuelio Hartlibo, moraviečio Komneno, Edinburge gimusio, o įvairiuose šiaurès Europos kraštuose išauklèto Johno Dury'o) bei jų Lietuvos, Lenkijos, Prūsijos, Šventosios Romos imperijos bendraminčių. Autoré apžvelgia 1699 m. sukurtos (bei iki šiol veikiančios) Draugijos krikščionių žinioms paskatinti veiklą, ypač jos paramą žemaičių evangelikams reformatams XVIII a. 4 dešimtmetyje. 